\title{
CIDADE, ESPAÇO PÚBLICO E CUIABANIA
}

\section{City, public space and cuiabania}

\author{
Nataniél Dal Moro*
}

\begin{abstract}
GUIMARÃES, Suzana Cristina Souza. Arte na rua: o imperativo da natureza. Cuiabá: EdUFMT, 2007. 184 p.
\end{abstract}

O livro intitulado Arte na rua: o imperativo da natureza é de autoria da pesquisadora e professora universitária Suzana Guimarães e foi apresentado no mês de abril de 2002 como dissertação de mestrado em História na Universidade Federal de Mato Grosso (UFMT). A publicação do respectivo trabalho foi viabilizada por meio de financiamento da Fundação de Amparo à Pesquisa do Estado de Mato Grosso (FAPEMAT).

A obra está estruturada da seguinte forma: agradecimentos, prefácio primoroso, que foi redigido pela orientadora da Suzana, a Profa. Dra. Ludmila Brandão, apresentação, três capítulos, considerações finais e referências, que se subdividem em: bibliografia, sites, jornais/revistas, pinturas nos espaços públicos e bibliotecas/arquivos.

A principal questão posta pela autora é a de saber como foi construída a identidade do povo cuiabano no decorrer da segunda metade do século XX, em especial nas décadas de 1970-80, localizando os sujeitos que empreenderam tal prática.

Guimarães quer saber quem é o cuiabano; quer saber quando e como ele surgiu; quer saber que sujeitos construíram a cuiabania e que instrumentos foram utilizados neste processo. Também aponta os sujeitos e os grupos sociais que colocaram em risco a típica cultura cuiabana. Nas palavras de Suzana, o intuito maior do seu texto é o de "historicizar a construção da relação arte-natureza-identidade em Cuiabá" (p. 172), em particular via fontes produzidas por determinados artistas plásticos.

\footnotetext{
Doutorando no Programa de Estudos Pós-Graduados em História na Pontifícia Universidade Católica de São Paulo (PUC-SP), sob a orientação da Profa. Dra. Yvone Dias Avelino. Bolsista CAPES. E-mail: natanieldalmoro@bol.com.br
} 
No primeiro capítulo, intitulado "Primeiro movimento - Fisionomia do passado", a pesquisadora demonstra, por meio de fontes as mais diversas, como a elite local sentiu-se desterritorializada em seu próprio território após receber na cidade de Cuiabá, sobretudo a partir da década de 1970, grande contingente de migrantes. Mostra como essa elite buscou defender, em particular no espaço citadino, a chamada cultura local frente ao avanço do que se chamou de cultura massiva, homogênea que passou a compor a realidade social cuiabana dos anos 70 do século XX em diante.

A cidade de Cuiabá passou a ser, com a migração ocorrida nas décadas de 1960-70, um local muito distinto daquele existente até os anos 50 do século XX. A cidade começou a ter mais gente, as favelas surgiam e aumentavam de tamanho, outros problemas passaram a existir, outras culturas passaram a ocupar a cidade e, cada vez mais, a cultura local/cultura típica deixava de fazer parte da vida cuiabana. Cada vez mais a cultura local se tornava menos hegemônica e os sujeitos que a produziam, e por ela eram representados, também se tornavam menos influentes no conjunto geral da sociedade.

Essa tendência de Mato Grosso de converter-se em receptor de fluxos migratórios oriundos da região Centro-Sul do país já se verificava no final da década de 60; todavia, foi no início dos anos 70 que assistimos à sua intensificação.

Por causa disso foi considerado como o último movimento de expansão da fronteira capitalista contemporânea no Brasil, a partir desse período. Nos anos posteriores, assistiu-se em Cuiabá à evolução paulatina dos mais variados movimentos sociais, inclusive o que se intitulou preservacionista dos bens e valores cuiabanos, considerados ameaçados diante dos impactos produzidos pelo processo de modernização. Esses movimentos privilegiavam o enfoque do impacto desse processo sobre a cultura.

Entre essas práticas regionalistas que tentaram afirmar e defender uma identidade cultural cuiabana preexistente, ao se tratar, poderíamos dizer, de um amplo processo de invenção (dessa identidade), foi possível identificar, por exemplo, como a construção de um discurso - inicialmente verificado entre os arquitetos que se inspiraram na memória espacial da tradição cultural - reelaborou uma arquitetura urbana, comprometida com uma espécie de estética identitária (p. 41-42). 
Este tipo de discurso está contido, segundo Suzana, nos escritos acadêmicos de Júlio De Lamonica Freire e de Ludmila Brandão, que, por sua vez, orientou o mestrado de Guimarães na UFMT.

Sendo assim, pode-se afirmar que nas décadas de 1960-70 houve todo um conflito entre a cultura regional e a cultura capitalista; contudo, a década de 1980 foi o ponto-chave deste processo. A primeira, dizia-se, estava desaparecendo e a segunda tornava-se cada vez mais hegemônica. Prova material do desaparecimento gradativo da cultura cuiabana estava nas demolições da Praça Alencastro (década de 1950), do Palácio Alencastro (1958) e da Catedral (1968).

E é por causa desses fatos que foi construído, no entender de Suzana, todo um conjunto de discursos que tinham como bandeira, grosso modo, defender a não demolição dos prédios antigos restantes, assim como almejavam tombar e restaurar algumas construções, já que estas significavam - ou passaram a significar no decorrer do processo - a cultura local, o genuinamente cuiabano. Destruindo estas construções, destruía-se igualmente a história do povo - leia-se muito mais a história da elite citadina do que propriamente do povo em geral.

A "perda, longe de expressar apenas a desintegração desse patrimônio espacial cuiabano, era um sentimento coletivo que atravessava diversos grupos sociais, particularmente o meio intelectual, os que se sentiam ameaçados de perder privilégios e lugares sociais conquistados" (p. 44-45), a saber: a elite local, composta, sobretudo, por estudantes, professores e intelectuais, que criou "um movimento citadino de defesa do Centro Histórico de Cuiabá, articulado principalmente pelos arquitetos associados ao IAB/MT (Instituto de Arquitetos do Brasil - Departamento de Mato Grosso)" (p. 43).

Suzana discute durante todo o livro a questão da cultura local e da nacional, do tradicional e do moderno, apoiando-se, para isso, nas reflexões feitas por Renato Ortiz, Stuart Hall, Alfredo Bosi e Suely Rolnik. Mostra como a migração das décadas de 1960-70 alterou extremamente o cotidiano urbano e as relações de força na cidade de Cuiabá. Mostra o quão poderosa é a arte visual, pois pode ser utilizada para construir uma identidade, assim como para destruir e/ou impedir a emergência de outra cultura, que nesse caso é a dos migrantes que chegaram à cidade de Cuiabá pelos mais diver- 
sos motivos, com destaque para o de (re)fazerem a vida em outro espaço: o espaço da fronteira agrícola.

De forma mais pontual, Guimarães analisa os posicionamentos do arquiteto e urbanista Júlio De Lamonica e da pesquisadora Ludmila Brandão sobre a preservação do centro histórico de Cuiabá, enfocando a base teórica que os balizou em seus estudos: os escritos de Antonio Gramsci como justificadores desta prática social e política que visou impedir a destruição da arquitetura cuiabana do período colonial brasileiro.

"Segundo momento - Iconografia cuiabana" é o título do segundo e principal capítulo do livro ora resenhado. Nesta parte da obra, a autora, que é doutoranda em História na Pontifícia Universidade Católica do Rio Grande do Sul (PUC-RS), busca confrontar a cidade de Cuiabá do passado, repleta de histórias dos bandeirantes, das monções e do ouro, com a Cuiabá do presente, inserida no mundo capitalista e na cultura de massas, que em parte não se sente atrelada ao outrora para poder existir plenamente do ponto de vista identitário. Busca analisar como a UFMT construiu a imagem do homem regional (p. 85).

A historiadora Suzana utilizou principalmente a fala de pessoas públicas, como a da artista plástica Aline Figueiredo e a do primeiro reitor pró-tempore da UFMT, Gabriel Novis Neves, para desenvolver este capítulo, no qual externa e analisa parte da produção pictórica feita nas décadas de 1970-80.

A UFMT, também conhecida e denominada publicamente como sendo Universidade da Selva, tornou-se o polo que centralizava, produzia e distribuía, enfim, fomentava de várias formas a legítima cultura cuiabana. Nesse sentido, a UFMT

abdicou de sua condição acadêmica tradicional, passando a investir na produção de um conhecimento científico que operava com um modo específico de subjetividade (identitária), definida como própria, autêntica, cuja realidade por ela configurada passaria a ser referência de si para outros, impondo uma espécie de marca regional (p. 89).

A Associação Mato-Grossense de Artes (AMA), criada na cidade de Campo Grande, sul do Estado de Mato Grosso, no ano de 1967, e o 
Museu de Arte e Cultura Popular (MACP), fundado em 1974, dentre outras instituições, são analisados como locais produtores - e guardiões - de uma determinada identidade cultural, a chamada identidade cuiabana. Identidade essa que buscava preservar o passado, sobretudo via preservação material, e exaltar o presente via iconografia da natureza existente no Estado de Mato Grosso ${ }^{1}$.

Uma das iniciativas do MACP foi fornecer todo aparato físico e intelectual para formar o artista mato-grossense. Esse apoio total e irrestrito veio através da instalação de dois ateliês de arte na cidade, o primeiro, criado em 1975 pela Fundação Cultural de Mato Grosso e assessorado diretamente pelos técnicos do MACP, e, mais tarde, o do próprio MACP, criado em 1981 (p. 122).

A iconografia artística feita na década de 1970, em grande parte fomentada pelo poder público, via UFMT, ajudou a construir uma outra identidade para o povo cuiabano, tendo como destaque as seguintes temáticas: culturas indígenas, povo caboclo, cultura material popular e natureza.

No capítulo 3, denominado "Terceiro movimento - Arte na rua", a autora investiga como foi construída historicamente a subjetividade local (p. 131) existente a respeito de uma arte que se dizia ser tipicamente cuiabana. A natureza presente na região passou a ser a fonte central, segura e inspiradora para a produção deste tipo de arte. Esta arte, com o decorrer do tempo, tornou-se referência e passou a dizer como tinha sido e como devia ser a cultura cuiabana. Era a cuiabania.

A cuiabania, na verdade os seus representantes, elegeram a pintura como "o veículo mais perfeito para a expressão da cultura cuiabana” (p. 138).

1 "Na esfera federal, encontramos o Museu do Índio (1971), o MACP (1974) e o Ateliê Livre do MACP (1981); na esfera estadual, a Fundação Cultural do Estado de Mato Grosso, a Casa do Artesão (1975), o Salão Jovem Arte Mato-grossense, o Ateliê Livre da Fundação Cultural, a Pinacoteca Estadual (1976), a Galeria Dalva Maria de Barros (1985); na esfera municipal, temos a Casa da Cultura (1975) e o Ateliê-Escola de Artes Plásticas (1982). Ainda fazendo parte do rol das instituições oficiais voltadas para a documentação da memória e história de Cuiabá, podemos citar, dentre outras, o Núcleo de Documentação e Informação Histórica Regional, da UFMT - NDIHR/UFMT -, criado em 1976, o Museu Histórico, o Museu de Arte Sacra da Fundação Cultural (1980) e o Instituto Memória do Poder Legislativo do Estado de Mato Grosso (1988)" (GUIMARÃES, 2007, p. 110-111). 
E foi no espaço público da cidade de Cuiabá que este tipo de arte plástica tomou materialidade.

Os "artistas plásticos de Cuiabá, a partir da década de 80, preocupados em socializar o acesso à arte da sua grande fonte inspiradora, os povos, inauguraram uma nova cultura visual, espalhando sua pintura nos muros, paredes, vitrines e lugares públicos da cidade" (p. 140-141).

O ano de 1983 sinaliza o início das pinturas individuais e das coletivas no espaço público da cidade; um boom deste tipo de arte, pois "50 artistas plásticos, na maioria autodidatas, participaram da exposição itinerante "Cuiabá: Um Grande Ateliê", aberta no Terminal Rodoviário de Cuiabá, com a presença e apoio de outros artistas da cidade, como poetas e músicos" (p. 144). Estas pinturas, para a historiadora Guimarães, seguiam a tendência da arte figurativa, da arte abstrata, enfocando desenhos de humor, externando poemas visuais e também realizando a arte xerox.

As imagens veiculadas eram as mais variadas, indo desde pinturas de gravações feitas em cavernas até arte eletrônica. O centro destas pinturas foi composto pelo tripé arte-natureza-identidade. Da página 66 até a 79 da obra resenhada, há doze fotos de pinturas realizadas na cidade de Cuiabá entre os anos de 1975 a 2001 pelos artistas plásticos Adir Sodré, Aleixo Cortez, Almira Reuter, Benedito Nunes, Carlos Lopes, Dalva de Barros, Gervane de Paula, Humberto Espíndola, Jonas Barros, Júlio César, Maty Vitart, Nilson Pimenta, Osvaldina dos Santos, Regina Pena e Sitó. A maioria das pinturas foi feita nas paredes de prédios e/ou de viadutos; contudo, veículos de transporte coletivo, como ônibus, também foram utilizados para frisar a já referida trilogia arte-natureza-identidade.

Para Suzana Guimarães, que já lecionou na UFMT e agora é professora do Departamento de História na Universidade do Estado de Mato Grosso (UNEMAT),

as artes plásticas produzidas em Cuiabá territorializam-se no fenômeno ambiental. A inspiração cotidiana é encontrada na fauna, na flora, na paisagem. O mundo animal é presença constante nas telas da maioria dos artistas; primeiramente, povoando o espaço físico da região, depois, o espaço imaginário (p. 158).

Nesse sentido, passa a ser "natural" a existência de artistas que produzem obras que retratam esta realidade, qual seja, a da natureza como 
algo dado e não como uma ação feita pelos sujeitos históricos. Este tipo de concepção, de ideologia mesmo, foi defendido, como bem demonstra Guimarães, por alguns artistas, dentre os quais estão Aline Figueiredo e Humberto Espíndola. "Mais que representar, essa visualidade que se intitula morena da cor da terra, da cor do índio, que transborda bichos e florestas, instaura/produz sentidos e significados, constrói realidade" (p. 165).

A obra denominada Arte na rua: o imperativo da natureza é, por todas estas questões externadas e outras mais, um escrito de grande valor acadêmico e, não menos, também social, pois, através de uma linguagem bastante clara, este livro ajuda sobremaneira a (re)pensar criticamente a história mato-grosssense e a problematizar de modo muito apurado a ideia de identidade nacional existente no Brasil.

De forma mais pontual Suzana mostra, e esse é um dos maiores méritos do seu trabalho, talvez o maior no meu entendimento, que a ação cultural via artes plásticas pode construir e também destruir identidades, bem ao estilo das reflexões contidas nos escritos do filósofo Walter Benjamin, embora ela não mencione este pensador no seu texto. Para Benjamin, "não há documento de cultura que não seja ao mesmo tempo um documento da barbárie"”.

Recebido em 22/02/2009. Aprovado em 02/10/2010.

2 BENJAMIN, Walter. Teses sobre filosofia da história. In: KOTHE, Flávio R. (Org.). Sociologia. São Paulo: Ática, 1985, p. 156. 